
8

\title{
Morphology of the sporophyte and gametophyte of the swamp fern Blechnum serrulatum (Blechnaceae, Pteridophyta)
}

\section{Running title: sporophyte and gametophyte of Blechnum serrulatum} (1)

C. H. Rolleri ${ }^{1}$, C. Prada ${ }^{2}$, J. M. Gabriel y Galán ${ }^{2}$, L. M. Passarelli ${ }^{1}$ and M. M. Ciciarelli ${ }^{1}$
${ }^{1}$ LEAVES (Laboratorio de Estudios de Anatomía Vegetal Evolutiva y Sistemática), Facultad de Ciencias Naturales y Museo de La Plata, 64 entre 120 y diagonal 113, B1904 DZB, La Plata, Argentina
2 Departamento de Biología Vegetal I, Facultad de Ciencias Biológicas, Universidad Complutense, Ciudad Universitaria, 28040 Madrid, España

$$
\text { Correspondence author: C. Prada,cpm@bio.ucm.es }
$$

\section{ABSTRACT}

A detailed study of the sporophyte and gametophyte of the swamp fern Blechnum serrulatum was carried out on specimens from distant localities of its wide geographical area. Characters under study were those of the external and internal morphology of axes, laminae and pinnae, indusia, and spores. The adaptive anatomy of the axes is particularly interesting: the rhizomes are internally massive, consisting of a loose parenchyma whose cells contain abundant starch, whereas the stipes are formed by aerenchyma, with diaphragms, very similar to the typical tissue found in any aquatic angiosperm. The intercellular pectic connections traversing the large intercellular spaces of the loose amylaceous parenchyma of the rhizome, and the filamentous protuberances, mainly cellulosic, of the cell walls in the diaphragms of the aerechyma with an external waxy impregnation, are here studied for the first time. The morphology of the gametophyte, from spore germination to the full development of gametophytes and gametangia formation, aim to complete an updated revision of the species. 


\section{INTRODUCTION}

Blechnum serrulatum Rich. is a pantropical, distinctive, evergreen species with a wide geographical range, covering from South Florida, South of Mexico, Mesoamerica, Antilles, to South America (Colombia, Venezuela, Trinidad, the Guianas, Ecuador, Peru, Bolivia, Brazil, Paraguay and Northeast of Argentina), Malaysia, and Australia. It grows in swamps, marshes, wet prairies, moist pine woods, forests, and low humid areas subject to periodical flow, mostly as an amphibious plant, but occurring also as a terrestrial, scandent to hemiepiphytic element in rain forests.

Tryon and Tryon (1982) proposed the $B$. serrulatum group, comprising this only species, characterized by large plants, with subterranean, short to long creeping rhizomes, erect to scandent, monomorphic, 1-pinnate fronds with articulate pinnae, living in tropical and subtropical America, and Malaysia to Australia. These authors considered the species as adventive in one of the two regions.

In the Neotropics, $B$. serrulatum has been treated in recent floras and catalogues by Nauman (1993), Tryon and Stolze (1993), Moran (1995), Smith (1995), Mickel and Smith (2004), Oliveira Dittrich (2005), and Rolleri and Prada (2006a).

Blechnum serrulatum has slender to coarse rhizomes with internal amylaceous parenchyma, and also develops a distinctive aerenchyma in stipes, a tissue most uncommon in ferns. The presence of aerenchyma was mentioned in general descriptions of the species, but its morphology has not been studied previously in detail.

Spores of $B$. serrulatum were illustrated by Tryon and Tryon (1982), Tryon and Lugardon (1991), Rolleri and Prada (2006b) and Passarelli (2007). With regard to the cytology, Walker (1985) registered a chromosome count of $n=36,2 n=72$ in material from Trinidad as a confirmation of other previous count from Jamaica [sub B. indicum]. Chambers and Farrant (1998) mentioned a chromosome count of $n=c a .37$, obtained by Brownlie (1965) for plants identified as B. indicum from New Caledonia.

The knowledge of the gametophyte generation is still scarce for neotropical species of Blechnum. Only B. buchtienii Rosenst. (Stokey and Atkinson 1952), B. hastatum Kaulf., B. magellanicum (Desv.) Mett., B. microphyllum (Goldm.) C. V. Morton, B. mochaenum Kunkel, B. penna-marina (Poir.) Kuhn (Rodríguez Ríos 1973), B. chilense (Kaulf.) Mett., B. cycadifolium (Colla) Sturm (Pérez García et al. 1996) and B. sprucei C. Chr. (Gabriel y Galán et al. 2008) have been studied in detail.

Despite of previous literature on the species, its morphological characters are not well known. The characters of the sporophyte under analysis were the external and 
1 internal morphology of axes and laminae, and the spores. The sexual phase of the

2 species was also analyzed, including the spore germination, the complete development of gametophytes and gametangia formation. Most of the internal traits were studied here for the first time, and adaptive and physiological aspects of the anatomy are discussed.

Based on the investigation made, a comprehensive morphological revision of the sporophyte and gametophyte of $B$. serrulatum is presented here, with an updated description of the species, as well as comments on its affinities, ecology and geographical distribution.

\section{MATERIAL AND METHODS}

Fresh and dry herbarium material was used for this study. Herbarium material for anatomical studies comes from CTES, BA, LP, MA, SI and UC (Holmgren et al. 1990). Selected representative specimens are also cited in Appendix I.

Small pieces of dry rhizomes and stipes were slowly hydrated in distilled water using a microwave oven. Time of soaking did not exceeded 7 seconds, and the procedure was repeated 3-4 times after leaving the pieces to be completely cool. This procedure allows to expand the tissues by slow imbibition and can be repeated every 24 hours. Tests sections were made during treatment to prevent any damage and make possible the aerenchyma expansion without breaking.

Scanning electron microscope observations of rhizomes, stipes and pinnae were conducted on hand-made transverse sections, let to dry at room temperature and mounted on metal stubs with double sided tape, covered with gold under vacuum and photographed with a Jeol /EO JSM 6360 (15 KV) SEM.

Several transverse sections of rhizomes and stipes were hand-made to analyze the different types of occurring tissues and intercellular protuberances (IP) under light microscope. Staining procedures were performed using 1\% aqueous Aniline blue, $1 \%$ Aniline blue in $70 \%$ ethanol, and $1 \%$ Vesubine (Bismarck brown $\mathrm{Y}$ ) in $70 \%$ ethanol to tests cellulose and callose; $1 \%$ aqueous Ruthenium Red, $1 \%$ aqueous TBO, and periodic acid-Schiff (PAS method) to detect pectin, Sudan IV to examine the presence

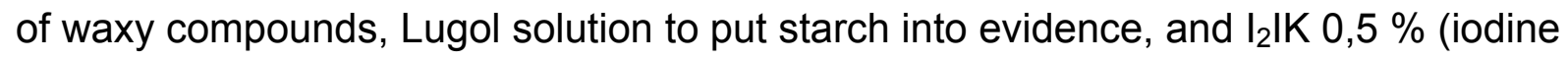
impregnation) to test xyloglucans (Johansen 1940; Gurr 1966; Ruzin 1999).

Tests for mucilage are as varied as the composition of this substance, and three different staining procedures were used: $1 \%$ aqueous Ruthenium Red, a very dilute 
1 solution of eosin, and $10 \%$ tannic acid in $70 \%$ alcohol, as a mordant, with a saturated

2 solution of ferric chloride in $70 \%$ alcohol, as a stain (Foster 1934). The mucilages containing neutral or acid carbohydrates give rosy to red colour responses to Ruthenium Red and the protein-containing mucilages gives light pink colour reaction to a very dilute solution of eosin. Besides, using the Foster's method, some mucilage give dark blue to black colour.

Venation and epidermal patterns were analyzed in basal, apical and medium pinnae, cleared with aqueous $6 \% \mathrm{NaOH}$, then coloured with aqueous $1 \%$ TBO (Gurr 1966). Only the medium pinnae were illustrated.

The size and density of stomata were measured in medium pinnae from all studied samples; values shown are the average of 25 measures per sample, and sizes are expressed as minimum, media and maximum length $\mathrm{x}$ width. Stomata density is expressed as minimum, media and maximum number of stomata $/ \mathrm{mm}^{2}$.

Spores were studied with SEM, mounted on metal stubs with double sided tape, covered with gold under vacuum and photographed with a Jeol /EO JSM 6360 (15 KV) SEM. Spores were also studied with light microscope, mounted in DePeX (DePeX mounting medium, Gurr, BDH Laboratory Supplies, Poole BH15 1TD, UK) and measured using an ocular micrometer. Measurements are based on a minimum sample of 100 spores taken from different specimens. Sizes are expressed as longest $x$ shortest equatorial diameters, as seeing both in polar view, in $\mu \mathrm{m}$.

Gametophytes were studied from material collected in Corrientes (Argentina) by one of the authors. Spore samples for cultures were taken from a single sporophyte. Multispore cultures on mineral agar medium (Dyer 1979) were established by sacking fertile pinnae on a paper, and placing the obtained spores in plastic Petri dishes $6 \mathrm{~cm}$ in diameter. The sowing was replicated twice. Gametophytes were grown under fluorescent light on a 12-h light, 12-h dark cycle at $20 \pm 2^{\circ} \mathrm{C}$. Percentage of germination was recorded for a random sample of 50 spores from each of the two plates, every three days until there was no further increase. To study the stages of gametophyte development and the sexual expression, random samples were taken weekly, from the beginning of spore germination until sexual maturity. Gametophytes were stained with chloral hydrate acetocarmine (Edwards and Miller 1972), mounted in water and observed under a light microscope. Also, in vivo observations were made.

Terminology related to sporophyte and gametophyte comes from Lellinger (2002); terms on stomata are applied after Prabhakar (2003), and those related to 
spores are in Lellinger and Taylor (1997).

\section{RESULTS}

The sporophyte

Blechnum serrulatum has large, non arborescent, rhizomatous sporophytes.

Rhizomes are stout, short to long-creeping, horizontal to erect branched, partly erect at tip, and sometimes scandent or climbing tree trunks. They are densely covered by dark brown scales, lanceolate to ovate in outline, 2-3 (5) $\mathrm{mm}$ long, with irregularly dentate to fimbriate margins (Fig. 1 A).

Transversal sections of rhizomes show the following tissues: a thickened, cutinized epidermis, a hypodermic area of several compact layers, a loose, central parenchyma with large intercellular spaces, and a dictyostele with 8-10 (15) meristeles of different diameters (Fig. $1 \mathrm{~B}$ ). The cells of the hypodermic area have thickened walls, with the appearance of a laminar collenchyma (Fig. $2 \mathrm{~A}$ ); cell walls are composed by a mix of cellulose and pectin, giving an intense rose hue when stained with Ruthenium Red and TBO, or red when using the PAS method. This area passes gradually to a central, amylaceous parenchyma, with large cells that accumulate abundant starch. Long, slender, irregularly intersecting connections are observed within the large intercellular spaces of this tissue (Fig. 2 B-C). Connections emerge from the primary wall of cells and intermingle randomly, giving the appearance of an irregular net of fine threads filling the intercellular spaces.

Reactions of this connections to Ruthenium Red, PAS method, and to the TBO tests indicate that they are pectic in nature.

Starch grains of parenchymatic cells are shortly cylindrical, 20-25 mu long, with a centre readily soluble in water, and a peripheral zone sparingly or not soluble at all. The slow imbibition of dry material used in this study tends to dissolve the centre of the grains but not the peripheral area, and they are sufficiently large to be cut when thin sections are made (Fig. $2 \mathrm{C}$ ).

Fronds are monomorphic, 30-50 (200) cm long, 7-16 (30) cm wide, with 1pinnate, erect to arching laminae. Stipes are glaucous to light brown, darker at base, 10-70 cm long, carnose yet firm to stiff in adult plants, almost circular in section, adaxially grooved, and abaxially rounded (Fig. $1 \mathrm{C}$ ), with basal lanceolate, acuminate, entire, reddish brown to bicolorous scales, then mostly glabrous. 
external, cutinized, thickened cell walls, a 20-30 layers thick hypodermic area with strongly sclerified cells (Fig. 2 D), a non amylaceous, parenchymatic tissue which include the stele, arranged in two large adaxial meristeles and up to 6-8 smaller meristeles (Fig. 1C), surrounded by an endodermis with Casparian strips, and fibrose tissue.

The central parenchymatic tissue becomes gradually a well developed aerenchyma, which occupies the whole centre of the stipe. Both aquatic/amphibian and terrestrial plants of the species develop aerenchyma. This tissue has diaphragms that intersect randomly leaving large air spaces (Fig. 1 D, 2 E-F). Several sections of aerenchyma suggest that it is schizogenous in origin, but the lacking of young plants to study the ontogeny of this tissue do not allow to be sure that some lysigenous via of origin combine with separation of cells. The aerenchyma was found in plants from several locations, and terrestrial plants do not show significant changes in the presence and distribution of this tissue.

Intercellular protuberances occur in the cell walls of diaphragms that contact air spaces (Fig. 3 A). They initiate as warts which grow to become filaments 6-7 $\mu \mathrm{m}$ long, densely distributed (Fig. 3 B). Filaments may be free or stick together, with the appearance of tufts of hairs. They are regularly or irregularly cylindrical, sometimes partially widened in the middle of their body, then tapering toward their apices; in some areas can be observed different lengths of these developing filaments. Traces of mucilage or a mucilage-like substance, rich in carbohydrates, with no appreciable amounts of protein were detected over them. Mucilage is not uncommon in aquatic plants, and may cause the sticking frequently observed among filaments. These IP reacted positively with Sudan IV, giving a strong orange-rosy color on their surface, whereas their whole body is dyed intensely blue with TBO. Xyloglucans, which usually give an intense blue color when impregnated with $\mathrm{I}_{2} \mathrm{IK}$, proved to be absent in these filaments, and no pectin was detected by means of TBO test, PAS method or Ruthenium Red. Tests for lignin and callose also proved negative. The tests performed indicate that the intercellular protuberances are primarily composed by cellulose and other primary cell wall polysaccharides, but also are externally impregnated by a shallow layer of a fatty substance.

Rachises are stramineous to brown, with scarce, abaxial indument, and costae are abaxially scaly. Scales of costae are small, up to $1 \mathrm{~mm}$ long, soft, irregular or triangular to deltoids, almost transparent, clear brown. Transversal 
sections of costae show a deep adaxial groove all along. The epidermis of the costa has small cells with thickened external walls, and a hypodermic fibrose-like tissue, with small, thickened cells; walls of these cells are not sclerified, with thickenings mainly composed by cellulose and hemicelluloses. A pair of hippocampiform vascular strands, surrounded by an endodermis with Casparian strips, are found in the central area. The abaxial area is prominent, round in section, and the tissue has cells with thickened walls composed by a mix of cellulose and pectin, highly hygrophilous, that closely resembles a laminar collenchyma (Figs. 1 E, 3 C-D).

Laminae are broadly oblong to oblong-elliptic or lanceolate, pinnate throughout, with a truncate base, glabrous, with a conform, non articulate terminal pinna, and up to 70 pairs of articulate lateral pinnae sessile to short-stalked, linearlanceolate to linear- oblong, adaxially glabrous, and abaxially slightly scaly, with scales mostly restricted to the costa, with serrulate margins. Venation is free, with visible veins irregularly bifurcate at similar distances to the costa (Fig. $1 \mathrm{~F}-\mathrm{H})$.

Epidermal patterns are sinuous both in epiphylls and hipophylls, and the epidermal cells have thin walls (Fig. 1 I-J). Epidermal cells of pinnae from aquatic and amphibians plants are somewhat smaller than the ones found in terrestrial plants, both in the epiphylls and the hipophylls. Stomata are elliptic in outline, slightly raised over the epidermis level; the guard cells have striate external walls and crenulate pores in all specimens studied. Anomocytic and diacytic types predominate in adult pinnae. Adult stomata are (30) 42 (48) x (22) 26 (27) $\mu \mathrm{m}$ and distribute with a density of (120) 148 (189) stomata / $\mathrm{mm}^{2}$.

Cenosori are costal, shorter than pinnae, and indusia are continuous, marginally erose to irregularly dentate, with subsinuous epidermal pattern (Fig. $1 \mathrm{~K}$ ).

Spores are light brown, monolete, ellipsoidal, (30) 35 (38) x (20) 24 (30) $\mu \mathrm{m}$, with perispore and are noticeably different from other species of Blechnum for having a perispore with spherical, slightly rugose orbicules (Fig. $3 \mathrm{E}$ ). The laesure is short, (24) 28 (36) $\mu \mathrm{m}$, and do not exceed half of the longest diameter of the spores. The perispore first deposits as a delicate yet continuous net, with a scabrate surface, that carry dense to scarce randomly distributed orbicules (Fig. 3 F). Orbicules are rugose and heterogeneous in size, which varies from $0,2-1,5 \mu \mathrm{m}$ in diameter. The exospore is smooth (Fig. 3 F). 
The gametophyte

(1)

$$
\begin{aligned}
& \text { during the first } 9-12 \text { days; afterwards, the germination raises rapidly to ca. } 60 \% \text {. A } \\
& \text { maximum percentage of } 74 \% \text { was recorded } 17 \text { days after sowing. }
\end{aligned}
$$

The spore germinates forming the first rhizoid and an initial prothallial cell, that divides in a perpendicular way to initiate the filamentous phase, which is very short, having no more than 2-4 cells (Fig. 4 A-B). After 12-15 days from germination, longitudinal divisions of apical and sub-apical cells derive in the formation of bidimensional prothallus (Fig. 4 C), which reach a spatulate shape (Fig. 4 D) in the following 12-17 days. During this stage, two unicellular capitate hairs develop at both extremes of the plate, in its widest zone. Subsequent divisions produce more hairs located along the apical portion of the prothallus. A central meristem becomes organized (Fig. $4 \mathrm{E}$ ), and finally, ca. 70 days after germination, a cordate, hairy gametophyte is formed, with two symmetrical wings (Fig. 4 F).

The gametophyte of $B$. serrulatum bears marginal, unicellular capitate hairs of about $40 \mu \mathrm{m}$ in length (Fig. $4 \mathrm{G}$ ), which become secretory. The highest density of the marginal indument locates on the superior line of the wings, and near the apical notch. Also, superficial hairs of similar size and morphology were found. The adult gametophyte presents a somewhat sinuous margin which tends to develop irregular projections that culminate in a hair, located in its medium-basal part (Fig. $4 \mathrm{H}$ ).

Gametophytes of $B$. serrulatum produce precociously antheridia: 45-60 days after germination, numerous morphologically juvenile prothalli show gametangia (Fig. 4 I). Antheridia are both superficial and marginal, and appear at any part of the gametophyte, but mostly on the medial zone. These antheridia seem to be deficiently formed, as many present only a few amorphous nuclei and normal spermatozoids have not been observed (Fig. $4 \mathrm{~J}$ ). At the same age, some female gametophytes, bigger than the precocious males, but either not completely developed, also appear in the cultures. Archegonia are scarce and located in the middle and superior parts of prothalli.

Female and bisexual gametophytes appear in the cultures ca. 65-80 days after germination. Gametangia are of the normal type and well-formed. In the female gametophytes, archegonia tend to occupy all the longitudinal central area of the prothallus, from the notch to almost the base. In the bisexual ones, antheridia appear in the superior part of the lamina, while archegonia develop in the middle and basal part of it. Finally, it is interesting to say that the archegonia appear in both abaxial and adaxial 
surfaces of the prothalli.

Around one year old gametophytes tend to grow losing the original cordate shape. In many of them vegetative proliferations, especially located in the apical margins of the prothalli, are developed.

\section{DISCUSSION}

The sporophyte

The species has very distinctive features in both the sporophyte and the gametophyte, and sporophyte characters analysed are coincident in specimens from locations throughout its wide geographical range of distribution. While margins may be somewhat variable, the variations are restricted to different depths of the serrated margins, whereas other external traits are similar in all specimens studied.

Hypodermic laminar-like collenchyma was found as mechanical support tissue in rhizomes, where a central parenchyma has large cells that accumulate abundant starch. Due to it, the rhizomes of $B$. serrulatum were consumed as an important source of carbohydrates by coastal aborigines groups of Australia (Iselin and Shipway 1999). Although this tissue has large intercellular spaces, it is not a typical aerenchyma but rather a loose parenchyma with large, starchy cells. While many specimens were analyzed, it is possible to find slight variations in the magnitude of the development and extension of aerenchyma in the stipe, whereas internal tissue of the rhizomes is better characterised as loose, somewhat spongy parenchyma that lacks diaphragms and lacunae. This condition is found in several aquatic angiosperms and the presence or absence of oxygen in the intercellular spaces of the rhizomes was considered as having no influence in the rate of growth, suggesting that the rhizomes are able to support a limited anaerobiosis, thus adapting to a certain deficiency of oxygen (Laing, 1941; Sculthorpe, 1971). This amylaceous tissue also characterizes by developing long, slender, irregularly intersecting pectic connections that intermingle randomly, filling the large intercellular spaces. This feature has not been reported in earlier studies.

Projections of cell wall surfaces into intercellular spaces were noted since De Vriese and Harting (1853). Potgieter and van Wyk (1992) made a detailed review of references to such excrescences found in the intercellular spaces of seeds, leaves, stems and roots of many monocotyledons, dicotyledons, ferns and fern allies; they referred these projections as pectic filaments, scalae and intercellular pectic protuberances or IPP. 
The pectic nature of the protuberances was first postulated by Mangin (1892, 1893), based on tests using different dyes, such as methylene blue and naphthalene blue. A synthesis of authors that identified pectin as the main constituent of IPPs was given by Leroux et al. (2007). Other constituents of the primary cell wall were also detected in IPPs: cellulose in Picea (Miller and Barnett 1993), xyloglucan in Hymenaea (Tiné et al. 2000), proteins and callose in Azolla (Veys et al. 1999), so the chemical composition of the cell wall protuberances is still under consideration.

Among the Pteridophyta, protuberances have been studied in Pteris L. (Schenck 1886), Blechnum L. (Schenck 1886), Equisetum L. (Vidal 1896), Pteridium L. (Carr and Carr 1975), Christensenia Maxon (Rolleri 1993), Azolla Lam. (Veys et al. 1999, 2000, 2002), Angiopteris Hoffm. (Carr and Carr 1975; Rolleri 2002), Archangiopteris H. Christ and Giesenh. (Mengascini 2002), Marattia Sw. (Lavalle 2003), Isoetes L. (Prada and Rolleri 2005), and Asplenium L. (Leroux et al. 2007). Although Potgieter and van Wyk (1992) considered the need of anatomical studies to justify the variability of occurence of these projections at specific and infraspecific levels, Carlquist (1957) reported infraspecific variation in the occurrence, form and distribution of IPPs for some Hawaiian Asteraceae, Potgieter and van Wyk (1992) for some African Icacinaceae, Prada and Rolleri (2005) for some Isoetes and some Blechnum species (Rolleri and Prada, 2006b), and Ciciarelli (2007) for some Cannaceae.

Although the intercellular protuberances were always considered as projections of the primary cell wall into intercellular spaces, the name currently in use, proposed by Potgieter and van Wyk (1992) was preceded by some other terms such as minute cellular spines (Hall 1971), microprojections (Hill and Camus 1986; Rolleri 1993), acicular spines (Marsden 1976), prolongaciones espiniformes (Prada 1979), among others. And so, the first and only mention of the IP of $B$. serrulatum comes from Jermy (1985), under the designation of internal, microscopic hairs; the author also refers to the aerenchyma of the stipe, but does not perform more detailed studies and considered the function of this internal hairs unknown.

As far as it is known to the present, characteristics, morphology and distribution of intercellular protuberances appear to vary in vascular plants. There has not been clearly related their presence with the taxonomy: they are found both in unrelated groups as much as in closely related genera (ie., the whole marattiaceous ferns); moreover, the known interpretations about its function are as variable as other data both on IP and IPP. 
Although the role of these IPP are much at issue, here could be part of a system of water balance in the stages of drought that experience marsh species. Amphibious habitat need a special water balance, and plants of $B$. serrulatum are exposed to strong solar radiation. The combination of external and internal characters suggests a coherent adaptation in relation to a habitat where water is always abundant or is regularly in excess, either by seasonal rains or flooding.

The sporophyte of $B$. serrulatum seems to be primarily adapted to amphibious life: the aerenchyma developed in the stipes was found in plants from several locations, and terrestrial plants do not show significant changes in the presence and distribution of this tissue, a character that strongly suggests that the aquatic/amphibian habitat is prior to land habitat.

The stipe is aerenchymatic, and develops within a well organized system of air chambers, with diaphragms that may help both with support of axis, and controlling the water flow inside the plant during flooding periods. Studies performed in many specimens suggest that aerenchyma develops schizogenously, but no study of the complete ontogeny of this tissue was made, and it is possible that some lysigenous via of origin combine with separation of cells.

Intercellular protuberances that initiate as warts and become long filaments occur in the cell walls of diaphragms that contact air spaces. These filaments are commonly free, but can be stick together in tufts in some areas, due to the mucilage detected over them, a substance common in aquatic plants, which performs various functions, from retain to block excess of water (Sculthorpe 1971). These IP are primarily composed by cellulose and other primary cell wall polysaccharides, but also are externally impregnated by a shallow layer of a undetermined fatty substance, possibly a secretion through the primary cell wall. The presence of pectin and lignin was discarded. It could be some kind of fatty acids, precursors of suberin, thus suggesting that this area could play some endodermic role.

References to the anatomy of the axes indicate the presence of aerenchyma in the rhizomes as well at the base of the stipe (Jermy 1985; Nauman 1993; Chambers and Farrant 1998), but the loose tissue of the rhizomes is less an aerenchyma and rather a massive, storage tissue with starch, while the aerenchyma is typical of the stipes and is found throughout its length.

The morphology of spores is uncommon in Blechnum, and the perispore with orbicules is similar to that of B. fernandezianum (Looser) Prada and Rolleri (Rolleri 
and Prada 2006b; Passarelli 2007). Tryon and Lugardon (1991) mentioned this type of perispore also for species of Platycerium Desv., Drynaria (Bory) Sm., Christiopteris Copel. and Polypodium L.

\section{The gametophyte}

The study of the gametophytes reveals that the germination pattern of $B$. serrulatum follows the Vittaria type, as the first prothallial cell emerged perpendicular to the first rhizoidal cell. This is the normal pattern for the leptosporangiate ferns (Nayar and Kaur 1968), and it has been previously reported for the genus (Pérez-García et al.1996; Gabriel y Galán et al. 2008).

Blechnum serrulatum presents the Aspidium model of morphological development (Nayar and Kaur 1969). Nevertheless, the typical Aspidium type implies the formation of a hair in the apical cell of the filamentous phase and laminar phase develops later. This typical pattern is followed by $B$. magellanicum (Rodríguez Ríos 1973). A deviation from the general pattern has been reported also by Nayar and Kaur (1969), in which there is a slight delay in the formation of the first hairs, so the bidimensional plate is formed prior to them. This type of developmental deviation is present in $B$. serrulatum and has been detected in other species, as $B$. hastatum, B. cycadifolium (Pérez-García et al. 1996) and B. sprucei (Gabriel y Galán et al. 2008).

Adult gametophytes of $B$. serrulatum are of the cordate, hairy type, previously reported for the Blechnaceae by Nayar and Kaur (1971) and Atkinson (1973). The vegetative morphology of the gametophytes varies in Blechnum: both hairy gametophytes, as in B. hastatum, B. magellanicum (Rodríguez Ríos 1973), B. cycadifolium (Pérez-García et al. 1996) and B. sprucei (Gabriel y Galán et al. 2008), and naked gametophytes, as in B. penna-marina, B. mochaenum, B. microphyllum (Rodríguez Ríos 1973) and B. chilense (Pérez-García et al. 1996), have been described. Secretory hairs have been previously observed in the genus (Nayar and Kaur 1971).

Regarding to the reproduction, there is also some variation in Blechnum species, as sometimes the sexual expression starts with the archegonia, as in $B$. serrulatum studied here, B. cycadifolium (Pérez-García et al.1996) and B. sprucei (Gabriel y Galán et al. 2008), or with the antheridia, as in B. hastatum, $B$. magellanicum, B. mochaenum, B. microphyllum and B. penna-marina (Rodríguez 
1 Ríos 1973). For $B$. chilense, both types of sexual expression have been reported

2 (Rodríguez Ríos 1973; Pérez-García et al. 1996).

In $B$. serrulatum, the coexistence in the cultures of male precocious gametophytes and female gametophytes could suggest the presence of an antheridiogen system (Raghavan 1989; Schneller et al. 1990). Antheridiogens are known to be operating in one species of the genus, B. brasiliense (Voeller 1964).

Remarks on the affinities between $B$. serrulatum and $B$. indicum

Blechnum serrulatum Rich. and B. indicum Burm. f., from Australia, Malaysia and New Caledonia, are two very similar species. The broad external morphology, the anatomy of all plant organs, and the morphology of the spores are identical in both species. Moreover, both grow in similar environments, related to the presence of abundant water in the soil or even in waterlogged soils. The differences used to distinguish the species do not exceed what is merely quantitative in some traits: grade in which the pinna margins is incised, grade in which the abaxial scales of costae are clathrate, grade in which the nerves are visible, grade in which pinnae are coloured (Chambers and Farrant 1998, 2001), and even these characters have been confused between the two species.

The presence of $B$. serrulatum in Australia is denied by Chambers and Farrant (2001), but these authors pointed out that "plants resembling $B$. serrulatum have been collected at several localities" in the country, "suggesting the species may be becoming naturalized". The adventive character of Blechnum serrulatum in Australia was first suggested by Tryon and Tryon (1982), while other authors cite it as a species present in Malaysia and Australia (Moran 1995).

It should also be noted that the names $B$. serrulatum and $B$. indicum have been used in a confusing way. Blechnum indicum was used to designate specimens from tropical America (Nelson 1977), being later placed, as B. indicum auct. non Burm., in the list of synonyms of $B$. serrulatum Rich. (Moran 1995; Funk et al. 2007). For its part, Chambers and Farrant (2001) include the name $B$. serrulatum auct. non Rich. as a synonym of $B$. indicum Burm., according to his view that $B$. serrulatum not live in Oceania.

Furthermore, it also remains to solve the problem of the type of $B$. indicum. According to Chambers and Farrant (2001), the type of $B$. indicum, from Java, would be lost, and these authors designated a neotype. But Morton (1970) had previously drawn 
attention to the fact that the type of $B$. indicum was a specimen of Asplenium. If that is true, the legitimate name and circumscription of $B$. indicum should be completely reviewed.

In any case, the results achieved in this study suggest that $B$. serrulatum and $B$. indicum could be the same species, due to the high amount of coincident characters. The quantitative variation discussed above could be admitted within the expected range of variation of a species. In this case, the name $B$. serrulatum Rich. should prevail, $B$. indicum Burm. f. becoming a synonym.

\section{ACKNOWLEDGMENTS}

This work was supported by the Proyecto de Investigación Fundamental $\mathrm{n}^{\circ}$ CGL2009-13622, Ministerio de Ciencia e Innovación, Spain.

\section{REFERENCES}

Atkinson LR (1973) The gametophyte and family relationships. Botanical Journal of the Linnean Society 67, 73-90.

Brownlie G (1965) Chromosome numbers in some Pacific Pteridophyta. Pacific Sci. 19, 493-497.

Carlquist S (1957) Leaf anatomy and ontogeny in Argyroxiphium and Wilkesia. American Journal of Botany 44, 696-705.

Carr SGM, Carr DJ (1975) Intercellular pectic strands in parenchyma: studies of plant cell walls by scanning electron microscopy. Australian Journal of Botany 23, 95105.

Chambers TC, Farrant PA (1998) Blechnaceae: Blechnum, Pteridoblechnum and Stenochlaena. Flora of Australia 48, 359-384.

Chambers TC, Farrant PA (2001) Revision of Blechnum (Blechnaceae) in Malesia. Blumea 46, 283-350.

Ciciarelli MM (2007) Canna ascendens Ciciarelli (Cannaceae) una nueva especie de la Provincia de Buenos Aires y comentarios de otras especies argentinas de este género. Darwiniana 45, 188-200.

De Vriese WH, Harting P (1853) 'Monographie des Marattiacées'. (Anz Co.: Leiden et Dusseldorf).

Dyer AF (1979) The culture of fern gametophytes for experimental investigation. In 'The experimental biology of ferns' (Eds AF Dyer) pp. 253-305. (Academic: London). 
1 Edwards ME, Miller JH (1972) Growth regulation by ethylene in fern gametophytes. III. Inhibition of spore germination. American Journal of Botany 59, 458-465.

Foster A (1934) The use of tannic acid and iron chloride for staining cell walls in meristematic tissue. Stain technol. 9, 91-92.

Funk V, Hollowell T, Berry P, Kelloff C, Alexander SN (2007) Checklist of the Plants of the Guiana Shield (Venezuela: Amazonas, Bolívar, Delta Amacuro; Guyana, Surinam, French Guiana). Contributions from the United States National Herbarium 55, 1-584.

Gabriel y Galán JM, Passarelli LM, Prada C, Rolleri CH (2008) Sporophyte morphology and gametophyte development of the fern Blechnum sprucei BlechnaceaePteridophyta. Revista de Biología Tropical 56, 2027-2040.

Gurr L (1966) 'The rational uses of dyes in biology'. (Williams and Wilkins: Baltimore). Hall JB (1971). Observations on Isoetes in Ghana. Botanical Journal of the Linnean Society 64, 117- 139.

Hill C, Camus J (1986). Evolutionary cladistics in Marattialean ferns. Bulletin of British Museum (Natural History), Botany 14, 219-244.

Holmgren PK, Holmgren NH, Barnett L (1990) 'Index Herbariorum, Part I: Herbaria of the World'. (New York Botanical Garden: New York).

Iselin M, Shipway L (1999) 'Plants: bush tucker, medicinal and other uses of Minjerribah'. (North Stradbroke Island Aboriginal and Islander Housing: North Stradbroke).

Jermy AC (1985). Cytotaxonomic studies on ferns of Trinidad, I. The climate, geology, and vegetation of Trinidad, with particular reference to the ecology of ferns. Bulletin of British Museum (Natural History), Botany 13, 133-147. Johansen DA (1940) 'Plant microtechnique'. (McGraw-Hill: New York).

Laing HE (1941) Effect of concentration of oxygen and pressure of water upon growth of rhizomes of semi-submerged water plants. Botanical Gazette 102, 712-724.

Lavalle M (2003) Taxonomía de las especies neotropicales de Marattia (Marattiaceae). Darwiniana 41, 61-68.

Lellinger DB (2002). A Modern Multilingual Glossary of taxonomic Pteridology. Pteridologia 3, $246 \mathrm{pp}$.

Lellinger DB, Taylor WC (1997). A classification of spore ornamentation in the Pteridophyta. In 'Holttum Memorial Volume' (Ed RJ Johns) pp. 33-42 (Royal Botanic Gardens: Kew). 
Leroux O, Knox JP, Leroux F, Vrijdaghs A, Bellefroid E, Borgonie G, Viane RLL (2007) Intercellular Pectic Protuberances in Asplenium: New Data on their Composition and Origin. Annals of Botany 100, 1165-1173.

Mangin ML (1892) Etude historique et critique sur la présence des composés pectiques dans les tissues des végétaux. Journal de Botanique 6, 12-19.

Mangin ML (1893) Recherches sur les composés pectiques (suite). Journal de Botanique 7, 120-131.

Marsden CR (1976). A new subspecies of Isoetes coromandelina from Northern Australia. Contributions from Herbarium Australiense 24,1-10.

Mengascini A (2002) Caracteres diagnósticos y taxonomía de 5 especies Archangiopteris Christ and Giesenh. (Marattiaceae Bercht. \& J.S. Presl). Revista del Museo de La Plata, Botánica 15, 3-22.

Mickel JT, Smith AR (2004)The Pteridophytes of Mexico. Memoirs of the New York Botanical Garden 88, 1-1054.

Miller H, Barnett JR (1993) The structure and composition of bead-like projections on Sitka spruce callus cells formed during grafting and in culture. Annals of Botany 72, 441-448.

Moran RC (1995) Blechnaceae. In 'Flora Mesoamericana 1' (Eds G Davidse, M Sousa, S Knapp) pp. 325-333 (Universidad Autónoma de México, Missouri Botanical Garden, The Natural History Museum: London).

Morton CV (1970). Recent fern literature. American Fern Journal 60,119-128.

Nauman CE (1993) Blechnum. In 'Flora of North America North of Mexico, Pteridophytes and gymnosperms, vol. 2' (Ed Flora of North America Editorial Committee) pp. 223-227 (Oxford University Press: New York).

Nayar BK, Kaur S (1968) Spore germination in homosporous ferns. Journal of Palynology 4, 1-14.

Nayar BK, Kaur S (1969) Types of prothallial development in homosporous ferns. Phytomorphology 19, 171-188.

Nayar BK, Kaur S (1971) Gametophytes of homosporous ferns. The Botanical Review 37 , 295-396.

Nelson, C (1977). Plantas Nuevas para la Flora de Honduras. Ceiba 21, 51-55.

Oliveira Dittrich VA (2005) Estudos taxonômicos no gênero Blechnum L. (PteridophytaBlechnaceae) para as regiões Sudeste e Sul do Brasil. PhD Thesis, Universidad Estadual Paulista Julio de Mesquita Filho. 
Passarelli LM (2007) Estudios esporales en especies del grupo Blechnum pennamarina (Blechnaceae, Pteridophyta). Acta Botanica Malacitana 32, 1-19.

Pérez-García B, Mendoza A, Ricci M (1996) Morfogénesis de la fase sexual de Blechnum chilense y Blechnum cycadifolium (Pterophyta: Blechnaceae). Revista de Biología Tropical 44, 491-497.

Potgieter MJ, van Wyk AE (1992) Intercellular pectic protuberances in plants: their structure and taxonomic significance. Botanical Bulletin of Academia Sinica 33, 295-316.

Prabhakar M (2003) Structure, delimitation, nomenclature and classification of stomata. Acta Botanica Sinica 46, 242-252.

Prada C (1979). Estudio de la anatomía foliar de las especies españolas del género Isoetes. Lagascalia 9:107-113.

Prada C, Rolleri CH (2005) A new species of Isoetes (Isoetaceae) from Turkey, with a study of microphyll intercellular pectic protuberances and their potential taxonomic value. Botanical Journal of the Linnean Society 147, 213-228.

Raghavan V (1989) 'Developmental biology of fern gametophytes'. (Cambridge University Press: Cambridge).

Rodríguez Ríos R (1973) Morfología de los protalos y algunos esporófitos jóvenes de algunas especies chilenas de Blechnum (Polypodiaceae s. I.). Gayana 22, 1-30.

Rolleri CH (1993) Revision of the genus Christensenia. American Fern Journal 83, 319.

Rolleri CH (2002) Caracteres diagnósticos y taxonomía en el género Angiopteris Hoffm. (Marattiaceae Bercht. \& J.S. PresI): I, Los caracteres. Revista del Museo de La Plata, Botánica 15, 23-49.

Rolleri CH, Prada C (2006a). Catálogo comentado de las especies de Blechnum (Blechnaceae-Pteridophyta) de Mesoamérica y Sudamérica. Anales del Jardín Botánico de Madrid 63, 67-106.

Rolleri CH, Prada C (2006b) Revisión de los grupos de especies del género Blechnum (Blechnaceae- Pteridophyta): el grupo B. penna-marina. Acta Botanica Malacitana 31, 7-50.

Ruzin SE (1999) 'Plant microtechnique and microscopy'. (Oxford University Press: London).

Schenck H (1886) Über die Auskleidung der Intercellulargänge. Berichte der Deutschen Botanischen Gesellschaft 3, 217-225. 
Schneller JJ, Haufler CH, Ranker TA (1990) Antheridiogen and natural gametophyte populations. American Fern Journal 80, 143-152.

Sculthorpe CD (1971) 'The biology of aquatic vascular plants'. (Edward Arnold: London).

Smith AR (1995) Blechnaceae. In 'Flora of the Venezuelan Guayana 2' (Eds JA Steyermark, PE Berry, BK Holst) pp. 23-29 (Missouri Botanical Garden Press: St. Louis).

Stokey AG, Atkinson LR (1952) The gametophyte of Blechnum spicant (L.) Wither. and B. buchtienii Rosenst. Phytomorphology 2, 9-15.

Tiné MAS, Cortelazzo A, Buckeridge MS (2000) Occurrence of xyloglucan containing protuberances in the storage cell walls of cotyledons of Hymenaea courbaril $\mathrm{L}$. Revista Brasileira de Botânica 23, 415-419.

Tryon RM, Lugardon H (1991) 'Spores of the Pteridophyta'. (Springer: New York).

Tryon RM, Stolze RG (1993) Pteridophyta of Peru, Part V. 18. Aspleniaceae-21. Polypodiaceae. Fieldiana: Botany, New Series 32, 1-190.

Tryon RM, Tryon A (1982) 'Ferns and allied plants, with special reference to tropical America'. (Springer: New York).

Veys P, Lejeune A, Van Hove C (2000) The pore of the leaf cavity of Azolla: interspecific morphological differences and continuity between the cavity envelopes. Symbiosis 29, 33-47.

Veys P, Lejeune A, Van Hove C (2002) The pore of the leaf cavity of Azolla species: teat cell differentiation and cell wall projections. Protoplasma 219, 31-42.

Veys P, Waterkeyn L, Lejeune A, Van Hove C (1999) The pore of the leaf cavity of Azolla: morphology, cytochemistry and possible functions. Symbiosis 27, 33-57.

Vidal $L$ (1896) Sur la présence de substances pectiques dans la membrane des cellules endodermiques de la racine des Equisetum. Journal de Botanique 10, 236-239.

Voeller BR (1964) Antheridiogens in ferns. In 'Régulateurs Naturels de la Croissance Végétale' (Ed Colloque International CNRS 12) pp. 665-684 (CNRS: Paris).

Walker TG (1985) Cytotaxonomic studies of the ferns of Trinidad. The cytologic and taxonomic implications. Bulletin of the British Museum of Natural History, Botany 13, 149-249. 
1 Appendix

2 Selected studied specimens (specimens with $\left({ }^{*}\right)$ were not investigated anatomically)

ARGENTINA. Corrientes: Departamento Santo Tomé, Ruta 41, Galarza, Reserva Natural

4 provincial Iberá, 0-100 m, Arbo \& al. 6551 y 6625 (LP). Departamento Mercedes, laguna lberá, Paso

5 Picada, Reserva Natural Provincial Iberá, Tressens \& al. 3669 (BA). San Cayetano, Cuenca Río

6 Riachuelo, s. coll., s. n. (SI 43950). San Miguel, Estancia San Juan Poriajhú, ruta 17, 18 km ruta 12,

7 Potrero El Rodeíto, Tressens et al. 4192 (CTES). Reserva Provincial del Iberá, Costa W de la Laguna

8 Iberá, Tressens et al. 4321 (CTES).

AUSTRALIA: [Sidney: New South Wales] "Bahía Botanica" (Botany Bay), Née s. n. (MA 213368).

Victoria: Melbourne: New South Wales, swamp 3 miles south of Nelson Bay, Filson 3594 (NDW) (*).

BELIZE: Belize, Belize International Airport, Dwyer 9106 (LP).

BRASIL. Distrito Federal: restinga de Marapendí, de la Sota 2286 (LIL, LP). Reserva Ecológica do IGBE, Area do Corrego Taquara, 1015 m, Fonseca \& Alvarenga 2154 (LP). Paraná: Villanova, Annies s. n. [Rosenstock filices Austrobrasil. Exsicc. 46] (BA5760). Paranaguá: Matinhos, Hatschbach 2438 (SI). Rio de Janeiro: Guanabara, restinga de Jacarepequá, próximo antigo Campo de Aviação, Pabst 8104 y 8105 (LP). “In arenosis humidis predominans", Guanabara: Tijuca, restinga de Itapeba, próximo a Estação Climatológica, Castellanos 23582 (LP). Guanabara: Tijuca, Reserva Biológica de Jacarepaguá, Strang 7548 (LP). Guanabara: Tijuca, Recreio dos Bandeirantes, "Casuarinas”, Strang 342 (LP). Guanabara: Tijuca, Strang 1164 (LP). Guanabara: Tijuca, Ilha do Govenador, Tubiacangá, Pabst \& Sick 7386 (HB 27669, LP). Rondônia: Basin of Rio Madeira, km 216-219, Madeira-Mamoré railroad, near Abunã, Prance \& al. 5825 (LP). Sãô Paulo: Campo, Estação Biológica, Campo Grande, 800 m, Smith 1998 (BA). 


\section{FIGURE CAPTIONS}

2 Figure 1. Anatomy of sporophyte of Blechnum serrulatum. A: Rhizomatic scales. B: Transversal section of rhizome.

3 C: Transversal section of stipe. D: Outline of the aerenchymatic cells and air spaces in transversal section of stipe. E:

4 Transversal section of costa. F: Pinna outline, with coastal coenosorus. G-H: Venation of pinna. G: Terminal portion

5 of pinna. $\mathrm{H}$ : Median portion of pinna. I: Epidermal pattern of the epiphyll. J: Epidermal pattern of the hipophyll. K:

6 Epidermal pattern of indusia. as, air spaces; $m t$, mechanical tissues; $p$, parenchymatic tissues; $v$, vascular strands.

$7 \quad$ Bar= $2 \mathrm{~mm}$ in $\mathrm{A} ; 3 \mathrm{~cm}$ in B; $1 \mathrm{~cm}$ in C; $100 \mu \mathrm{m}$ in D; $0.5 \mathrm{~mm}$ in E; $1 \mathrm{~cm}$ in F; $6 \mathrm{~mm}$ in G-H; $50 \mu \mathrm{m}$ in I-J; $0.3 \mathrm{~mm}$ in $\mathrm{K}$.

Figure 2. Rhizome (A-C) and stipe (D-F) anatomy in Blechnum serrulatum. A: Transversal section of hypodermic collechymatose area. B: Panoramic view of central amylaceous parenchyma. C: Details of central amylaceous parenchyma. D: Transversal section of hypodermic fibrose area. E: Panoramic view of central aerenchyma. F: Details of aerenchymatic cells and air passages. coll, collenchymatose tissue; ipc, intercellular pectic connections; s, starch grain. Bar= $200 \mu \mathrm{m}$ in $\mathrm{A} ; 50 \mu \mathrm{m}$ in $\mathrm{B}, \mathrm{D} ; 20 \mu \mathrm{m}$ in $\mathrm{C} ; 70 \mu \mathrm{m}$ in $\mathrm{E} ; 10 \mu \mathrm{m}$ in $\mathrm{F}$.

Figure 3. Aerenchymatic cells (A, B), pinna anatomy (C, D) and spore (E, F) of Blechnum serrulatum. A: Cells with contacting walls. B: intercellular filamentous protuberances and warts. C: Transversal section of costa, with adaxial hypodermic sclerified tissue, abaxial collenchymatose tissue, and two hippocampiform vascular strands. D: Detail of abaxial collenchymatose tissue. E: Variation of distribution and density of orbicules in perispore (Argentina, Tressens \& al. 3669, BA). F: Detail of perispore. ex, exospore; pe, perispore. Bar= $35 \mu \mathrm{m}$ in A; $2.4 \mu \mathrm{m}$ in B; $120 \mu \mathrm{m}$ in C; 30 $\mu \mathrm{m}$ in $\mathrm{D} ; 13 \mu \mathrm{m}$ in $\mathrm{E} ; 10 \mu \mathrm{m}$ in $\mathrm{F}$.

Figure 4. Gametophyte of Blechnum serrulatum. A: Germinating spore, 1 day. B: Uniseriate filamentous gametophyte, 4 days. C: Initial form of the bidimensional stage, 15 days. D: Spatulate gametophyte, showing the first two hairs, 30 days. E: Initial form of the cordate stage, 45 days. F: Adult gametophyte, 70 days. G: Detail of marginal hairs, 70 days. $\mathrm{H}$ : Irregular projections of the margin, 70 days. I: Inmature, precocious male gametophyte, showing 5 superficial antheridia and 1 marginal antheridium, 50 days. J: Detail of a precocious antheridium, showing some morphologically malformed nuclei, 50 days. Days are from germination. Bar: $70 \mu \mathrm{m}$ in A-C; $0.8 \mathrm{~mm}$ in D, F; $1.2 \mathrm{~mm}$ in $\mathrm{E}, \mathrm{I} ; 45 \mu \mathrm{m}$ in $\mathrm{G} ; 26 \mu \mathrm{m}$ in $\mathrm{H} ; 12 \mu \mathrm{m}$ in $\mathrm{J}$. 

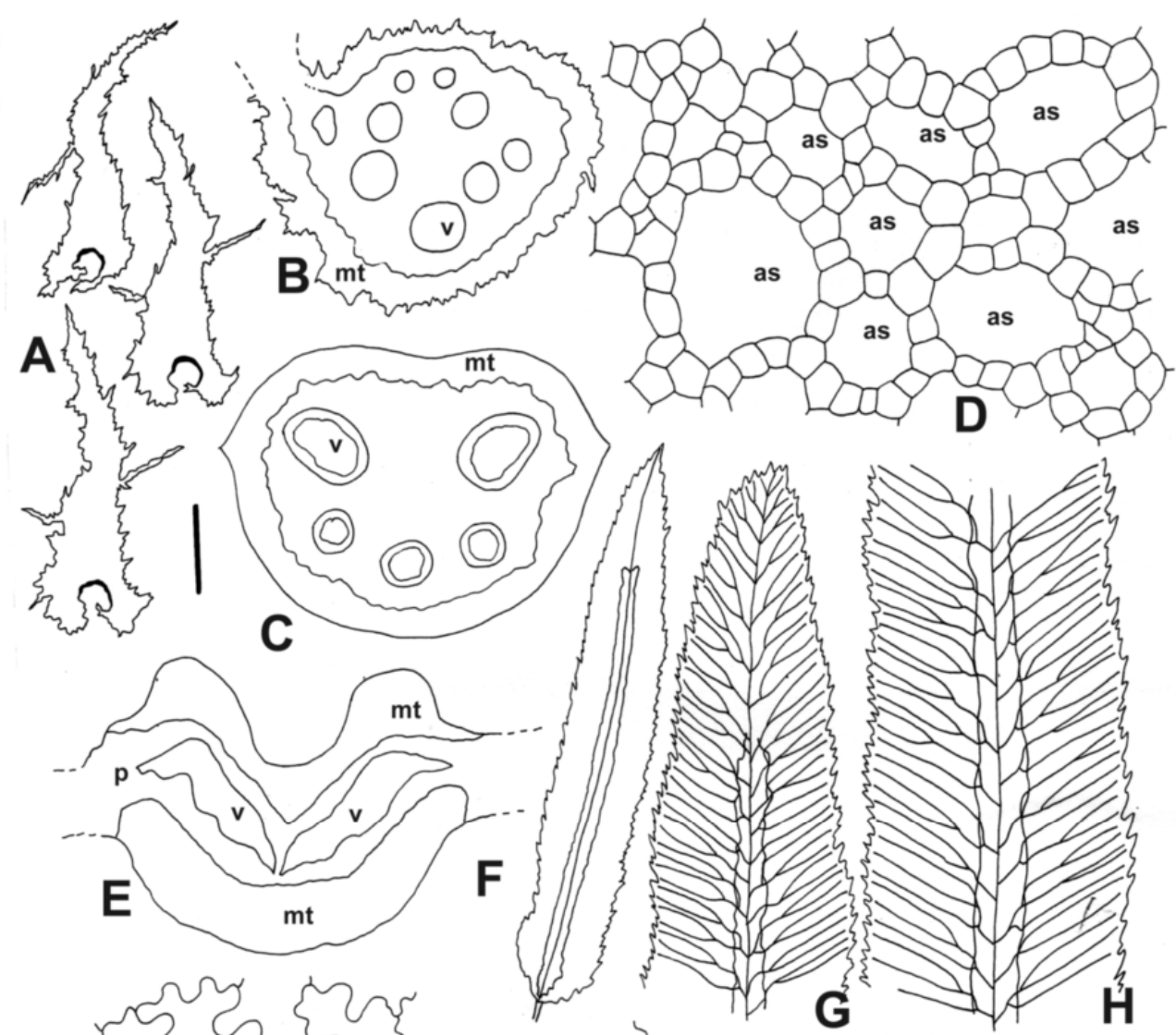

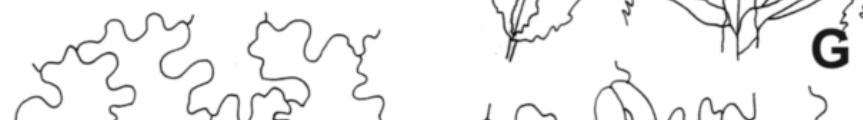
\{ 5 दु⿰ ज. दू का द 5nctis 


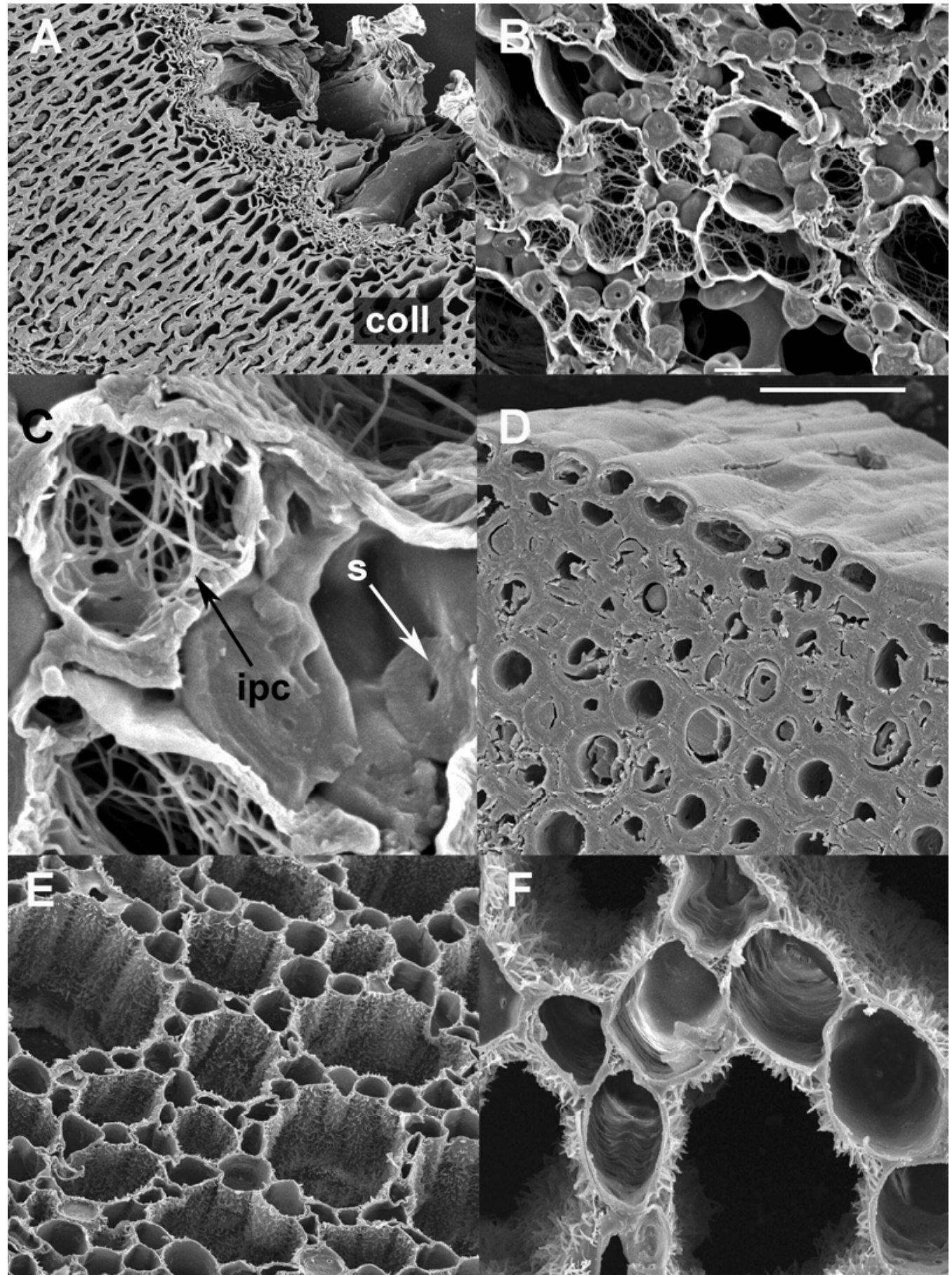




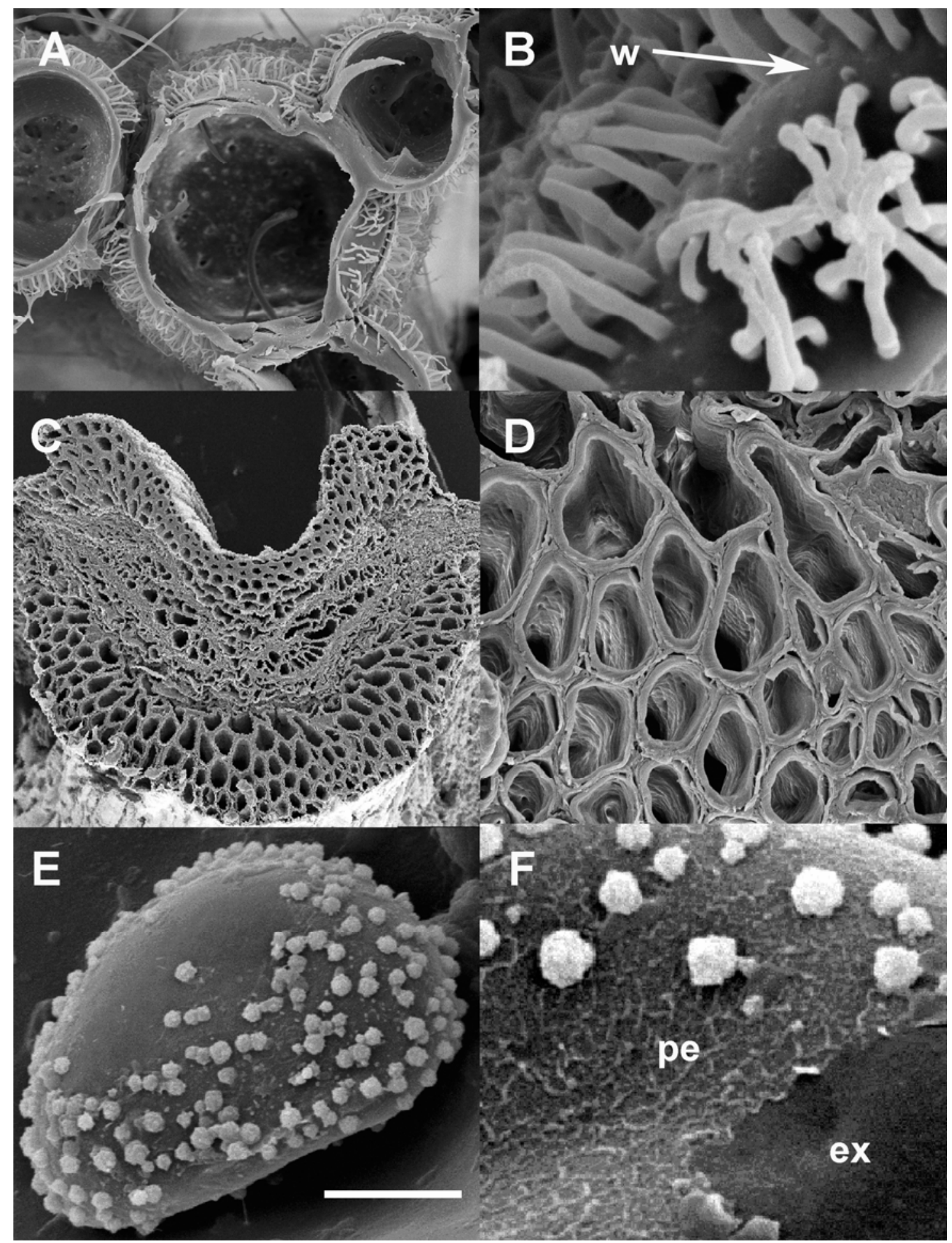




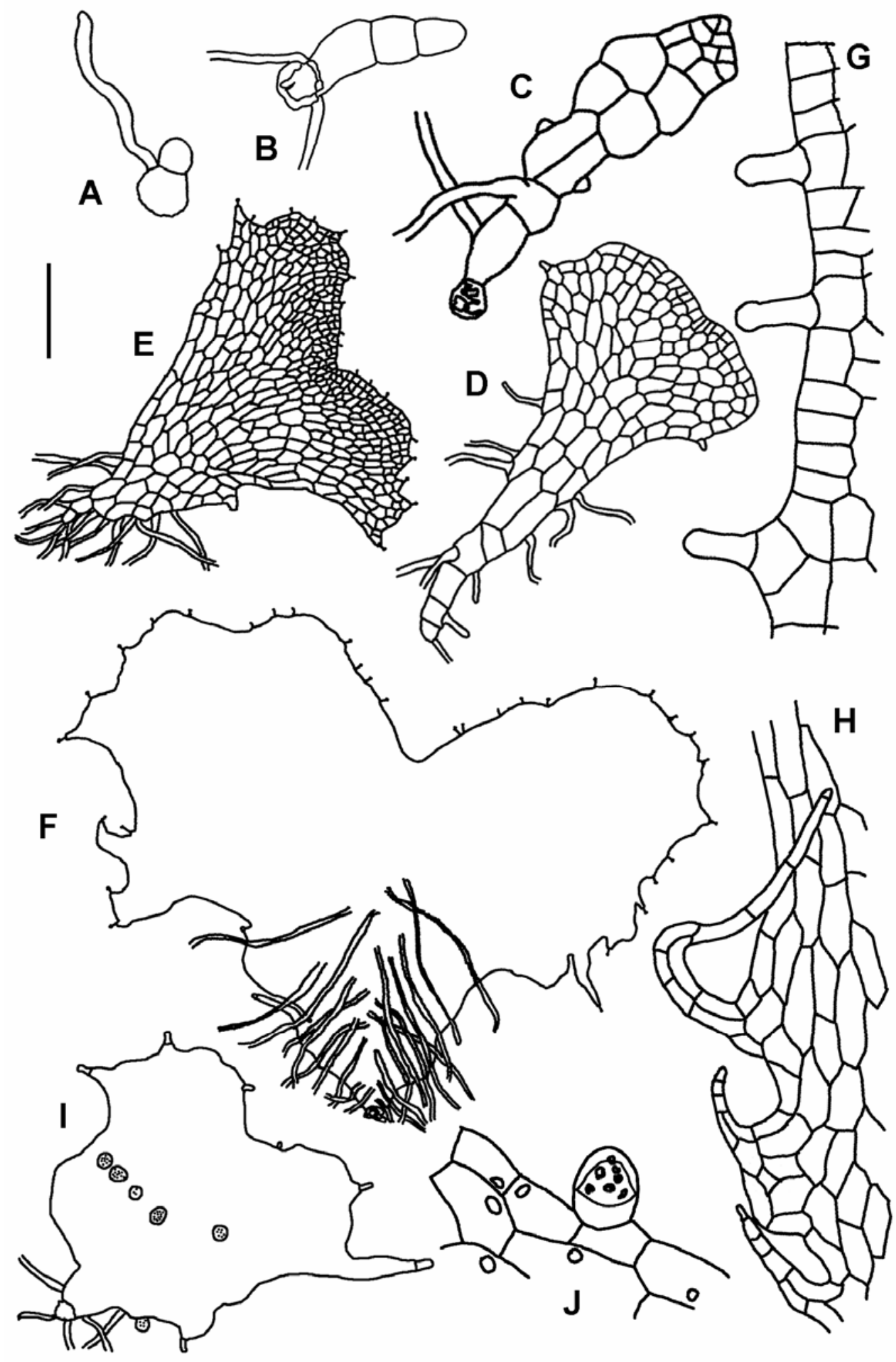

